\title{
Varicella Zoster and Cutaneous Candida Infection in a Patient With Ankylosing Spondylitis Under Treatment With Secukinumab
}

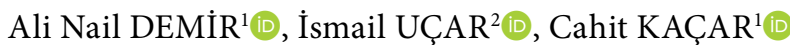 \\ ${ }^{1}$ Department of Physical Medicine and Rehabilitation, Division of Rheumatology, Akdeniz University Faculty of Medicine, Antalya, Turkey \\ ${ }^{2}$ Department of Internal Medicine, Division of Rheumatology, Akdeniz University Faculty of Medicine, Antalya, Turkey
}

Ankylosing spondylitis (AS) is a progressive chronic inflammatory disease primarily affecting the axial skeletal system. ${ }^{1,2}$ Interleukin (IL)-23/IL-17 axis plays role in the pathogenesis of AS. ${ }^{3}$ Secukinumab, anti-IL-17A, is a new agent for treating spondyloarthritis. In this article, we present a patient who developed varicella zoster and cutaneous candida infection following secukinumab treatment.

A 26-year-old male patient presented with low back, hip pain and morning stiffness in 2013 and was diagnosed with AS upon family history, human leukocyte antigen B27 positivity and presence of bilateral grade 3 sacroiliitis radiographically. He had symptoms and complaints related to AS although he had taken non-steroidal anti-inflammatory drugs and sulfasalazine at therapeutic dosages for longterm. He had a modified Schober of $2 \mathrm{~cm}$ and a Bath Ankylosing Spondylitis Disease Activity Index of 5.7, with increased acute phase reactants (C-reactive protein: $4.95 \mathrm{mg} / \mathrm{dL}$, erythrocyte sedimentation rate: $50 \mathrm{~mm} /$ hour). Secukinumab treatment was planned $(150 \mathrm{mg} /$ week for four weeks, followed by $150 \mathrm{mg} /$ four weeks).
After the first dose, a painful, itchy, vesicular rash in the right thoracic 6-8 dermatomal regions evolved (Figure 1). The rash was evaluated by a dermatologist and diagnosed as 'classical varicella zoster'. Secukinumab treatment was stopped and topical antiviral treatment was planned. After two weeks, the lesions completely regressed and secukinumab was resumed. In the fourth month of the treatment, an itchy hyperemic lesion, $10 \times 7 \mathrm{~cm}$ in diameter, with active erythematous edge and pale in the middle over the left lower quadrant of the abdomen evolved (Figure 2). The patient was referred to a dermatologist again; candida spores were seen in the microscopic examination and diagnosed as 'cutaneous candidiasis'. Secukinumab was stopped and systemic itraconazole plus topical sertaconazole treatment was started. After the treatment of cutaneous candidiasis, $50 \mathrm{mg} /$ week subcutaneous etanercept treatment was started.

Secukinumab has been approved in AS treatment recently and started to be used in rheumatology practice. IL-17A has an important role in immune responses against mucosal and cutaneous infections. IL-17-mediated immunity is needed for the protection of the skin and mucous

Received: April 14, 2019 Accepted: June 26, 2019 Published online: November 06, 2019

Correspondence: İsmail Uçar, MD. Akdeniz Üniversitesi Tıp Fakültesi İç Hastalıkları Anabilim Dalı, Romatoloji Bilim Dalı, 07070 Konyaaltı, Antalya, Turkey. Tel: +90 505 - 2294926 e-mail: dr.ismailucar@gmail.com 


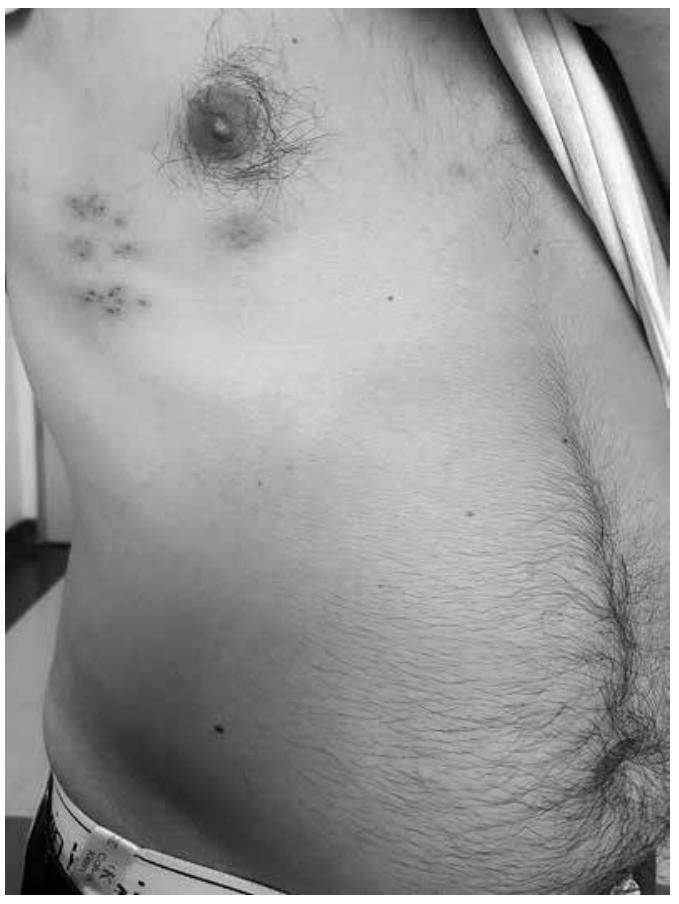

Figure 1. Vesicular rash in right thoracic 6-8 dermatomal regions.

membranes against candida albicans. Recurrent and persistent mucocutaneous candidiasis has been reported in patients who have genetic defects causing IL-17-related immune disturbances. ${ }^{4}$ For this reason, increased frequency of candida infections may be expected in patients treated with IL-17A antagonists. ${ }^{5}$

In phase 3 studies of secukinumab on AS and psoriatic arthritis, candida infections are increased as expected. Candida infections were observed in 68 of the 3,133 patients. ${ }^{6-12}$ Most of these were oral, vulvovaginal and esophageal candidiasis. Cutaneous candidiasis was reported only in one patient. ${ }^{6-12}$ Case numbers have been determined to be higher in psoriatic arthritis studies.

To our knowledge, secukinumab studies lack any information about the development of varicella zoster infection. In our patient, dermatomal herpes zoster infection developed after the first loading dose of the treatment. Considering the increasing use of secukinumab in rheumatologic patient groups, prospective studies with more patients and longer follow-up are required to assess the risk of infections such as herpes zoster or candida.

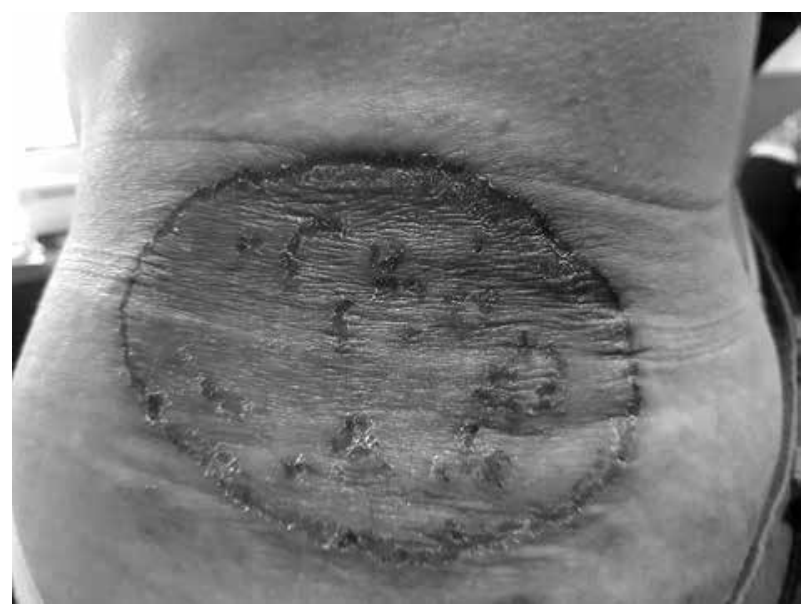

Figure 2. Lesion of cutaneous candidiasis.

\section{Declaration of conflicting interests}

The authors declared no conflicts of interest with respect to the authorship and/or publication of this article.

\section{Funding}

The authors received no financial support for the research and/or authorship of this article.

\section{REFERENCES}

1. Gao X, Wendling D, Botteman MF, Carter JA, Rao S, Cifaldi M. Clinical and economic burden of extra-articular manifestations in ankylosing spondylitis patients treated with anti-tumor necrosis factor agents. J Med Econ 2012;15:1054-63.

2. Giacomelli R, Gorla R, Trotta F, Tirri R, Grassi W, Bazzichi L, et al. Quality of life and unmet needs in patients with inflammatory arthropathies: results from the multicentre, observational RAPSODIA study. Rheumatology (Oxford) 2015;54:792-7.

3. Lubberts E. The IL-23-IL-17 axis in inflammatory arthritis. Nat Rev Rheumatol 2015;11:415-29.

4. Ling Y, Puel A. IL-17 and infections. Actas Dermosifiliogr 2014;105:34-40.

5. Yiu ZZ, Griffiths CE. Interleukin 17-A inhibition in the treatment of psoriasis. Expert Rev Clin Immunol 2016;12:1-4.

6. Mease PJ, Kavanaugh A, Reimold A, Tahir H, Rech J, Hall S, et al. Secukinumab in the treatment of psoriatic arthritis: efficacy and safety results through 3 years from the year 1 extension of the randomised phase III FUTURE 1 trial. RMD Open 2018;4:e000723.

7. McInnes IB, Mease PJ, Schett G, Kirkham B, Strand $\mathrm{V}$, Williams $\mathrm{N}$, et al. Secukinumab provides rapid and sustained pain relief in psoriatic arthritis over 2 years: 
results from the FUTURE 2 study. Arthritis Res Ther 2018;20:113.

8. Nash P, Mease PJ, McInnes IB, Rahman P, Ritchlin CT, Blanco R, et al. Efficacy and safety of secukinumab administration by autoinjector in patients with psoriatic arthritis: results from a randomized, placebo-controlled trial (FUTURE 3). Arthritis Res Ther 2018;20:47.

9. Mease P, van der Heijde D, Landewé R, Mpofu S, Rahman $\mathrm{P}$, Tahir $\mathrm{H}$, et al. Secukinumab improves active psoriatic arthritis symptoms and inhibits radiographic progression: primary results from the randomised, double-blind, phase III FUTURE 5 study. Ann Rheum Dis 2018;77:890-7.

10. Braun J, Baraliakos X, Deodhar A, Poddubnyy D, Emery $\mathrm{P}$, Delicha EM, et al. Secukinumab shows sustained efficacy and low structural progression in ankylosing spondylitis: 4-year results from the MEASURE 1 study. Rheumatology (Oxford) 2018 Dec 19.

11. Marzo-Ortega H, Sieper J, Kivitz A, Blanco R, Cohen M, Martin R, et al. Secukinumab and Sustained Improvement in Signs and Symptoms of Patients With Active Ankylosing Spondylitis Through Two Years: Results From a Phase III Study. Arthritis Care Res (Hoboken) 2017;69:1020-9.

12. Pavelka K, Kivitz A, Dokoupilova E, Blanco R, Maradiaga M, Tahir $\mathrm{H}$, et al. Efficacy, safety, and tolerability of secukinumab in patients with active ankylosing spondylitis: a randomized, double-blind phase 3 study, MEASURE 3. Arthritis Res Ther 2017;19:285. 